\title{
OVERVIEW OF PASSIVE SAMPLING TECHNIQUES FOR GROUNDWATER MONITORING
}

\author{
Wafa Illoul \\ PhD student, Institute of Environmental Management, University of Miskolc, Hungary \\ 3515 Miskolc, Miskolc-Egyetemváros, e-mail: qbailloul@uni-miskolc.hu
}

\begin{abstract}
This document presents an overview of passive sampling technologies applied in groundwater monitoring. It contains an overview of this innovative sampling technology showing the different background theories for organic and for inorganic contaminants; then, the paper focuses on one device for both types of contaminants, discussing its advantages, limitations, and development status in detail.
\end{abstract}

Keywords: passive sampling, passive samplers, monitoring, contaminants.

Abbreviations: BTEX, Benzene, toluene, ethylbenzene and xylene; DBL, Diffusive boundary layer; DET, Diffusion equilibrium in thin films; DGT, Diffusive gradient in thin films; LDPE, Low-density polyethylene; MESCO, Membrane-enclosed sorptive coating; nd-SPME, Negligible depletion solidphase microextraction; PAH, Polycyclic aromatic hydrocarbon; PCB, Polychlorinated biphenyl; PDB, Polyethylene diffusion bag; PIMS, Passive integrative mercury sampler; PLM, Permeation liquid membrane; SBSE, Stir-bar sorptive extraction; SLM, Supported liquid membrane; SLMD, Stabilized liquid-membrane device; SPMD, Semi-permeable membrane device; TWA, Time-weighted average; VOC, Volatile organic compound.

\section{Introduction to passive sampler technologies}

Sampling and analysis of organic (e.g., chlorophenols, organo- chlorine pesticides, polyaromatic hydrocarbons, polychlorinated biphenyls) and inorganic (e.g., heavy metals and some of their organometallic species) compounds represents an ongoing challenge to the environmental chemist. [1]

The passive groundwater sampler is defined as acquiring a sample from a discrete position in a well without active media transport induced by pumping or purging techniques. [2]

Passive samplers usually combine sampling, selective analyte isolation, preconcentration, and, in some cases, speciation preservation in one step. The operations performed at the sampling site are simplified by passive sampling. They eliminate the need for an energy/power supply and allow the entire sampling set-up to be miniaturized. When the samples are collected, further steps in their processing are usually the same as for other sampling preconcentration methods in analysis. They include extraction/desorption of the analytes, final instrumental analysis, and processing of the data.

In the following, several samplers with potential for use in groundwater monitoring programs are presented to illustrate the applications of this technology. [3]

\section{Advantages and limitations of passive sampler technologies}

Passive sampler technologies have advantages and limitations specific to the nature of each technology. In the following, several pros and cons of passive samplers are cited: 


\subsection{Advantages of passive sampler technologies}

- are relatively easy to use and can be deployed in most wells;

- are practical for use where access is difficult or where discretion is desirable;

- can sample discrete intervals in a well;

- can be deployed in series to provide a vertical contaminant profile;

- have no depth limit;

- reduce field sampling variability, resulting in highly reproducible data;

- allow rapid field sample collection;

- decrease field labor and project management costs for long-term monitoring;

- eliminate purge-water production and thus all or most disposal cost. [4]

\subsection{Limitations of passive sampler technologies}

- must be submerged in the screened interval during deployment;

- require the aquifer to be in hydraulic communication with the screened portion of the well;

- require special consideration in wells having a layer of free product;

- may have volume/analyte limitations;

- require consideration of contaminant stratification. [4]

\section{Classes of passive samplers/ passive sampling devices}

The passive samplers in this document will be classified into two categories:

- Passive samplers for organic pollutants

- Passive diffusion bag samplers

- Membrane enclosed sorptive coating

- Semi-permeable membrane devices

- Negligible depletion-solid phase microextraction

- Solvent-filled dialysis membranes

- Solid-phase microextraction applied for the determination of TWA concentrations

- LDPE and silicone strips

- Passive samplers for inorganic pollutants

- Diffusion gradients in thin films

- Permeation liquid membrane

- Passive integrative mercury sampler

- Stabilized liquid membrane device

- Supported liquid membrane and chemcatcher

Tables 1 and 2 below present an overview of devices used to measure organic and inorganic contaminants in water.

\subsection{Passive diffusion bag samplers (PDB) for volatile organic compounds (VOCs) elimination}

PDB samplers are used for collecting groundwater samples from wells. They offer a cost-effective approach to long-term monitoring of volatile organic compounds (VOCs) at well-characterized sites. $[5,6]$ 
Table 1. Passive sampling devices for organic contaminants

\begin{tabular}{|c|c|c|c|c|c|c|c|c|}
\hline Sampler & Name & Purpose & Analytes & Construction & Advantages & $\begin{array}{c}\text { Incon- } \\
\text { venience }\end{array}$ & $\begin{array}{c}\text { Deploy- } \\
\text { ment }\end{array}$ & $\begin{array}{l}\text { Refe- } \\
\text { rence }\end{array}$ \\
\hline PDB & $\begin{array}{l}\text { Passive } \\
\text { diffusion } \\
\text { bag } \\
\text { samplers }\end{array}$ & $\begin{array}{l}\text { Equilibrium } \\
\text { sampling in } \\
\text { ground- } \\
\text { water }\end{array}$ & $\begin{array}{l}\text { Polar organic } \\
\text { compounds, } \\
\text { VOCs, } \\
\text { metals, trace } \\
\text { elements }\end{array}$ & $\begin{array}{c}\text { Dialysis } \\
\text { membrane or } \\
\text { a low-density } \\
\text { polyethylene } \\
\text { bag filled } \\
\text { with distilled } \\
\text { water }\end{array}$ & $\begin{array}{l}\text { Relatively } \\
\text { inexpensive, } \\
\text { and sample } \\
\text { recovery is } \\
\text { rapid }\end{array}$ & $\begin{array}{l}\text { Not suitable } \\
\text { for sampling } \\
\text { semi-volatile } \\
\text { organic } \\
\text { compounds }\end{array}$ & 2 weeks & [7] \\
\hline MESCO & $\begin{array}{c}\text { Membrane } \\
\text { - enclosed } \\
\text { sorptive } \\
\text { coating }\end{array}$ & Integrative & $\begin{array}{l}\text { PAHs, PCBs, } \\
\text { organochlorin } \\
\text { e pesticides }\end{array}$ & $\begin{array}{l}\text { PDMS-coated } \\
\text { stir bar used } \\
\text { in SBSE or a } \\
\text { PDMS rod } \\
\text { enclosed in a } \\
\text { membrane } \\
\text { made of } \\
\text { regenerated } \\
\text { cellulose or } \\
\text { low-density } \\
\text { polyethylene }\end{array}$ & $\begin{array}{l}\text { Miniaturized } \\
\text { sampler, non- } \\
\text { depletive matrix } \\
\text { extraction, } \\
\text { solventless } \\
\text { sample } \\
\text { processing, and } \\
\text { both non-polar } \\
\text { and polar } \\
\text { analytes are } \\
\text { accumulated in } \\
\text { the sampler } \\
\text { equipped with a } \\
\text { cellulose } \\
\text { membrane }\end{array}$ & $\begin{array}{c}\text { Low } \\
\text { membrane } \\
\text { stability of } \\
\text { the sampler } \\
\text { variant with a } \\
\text { cellulose } \\
\text { dialysis } \\
\text { membrane }\end{array}$ & 2 weeks & [8] \\
\hline SPMD & $\begin{array}{c}\text { Semi- } \\
\text { permeable } \\
\text { membrane } \\
\text { devices }\end{array}$ & Integrative & $\begin{array}{l}\text { Hydrophobic } \\
\text { semi-volatile } \\
\text { organic } \\
\text { compounds }\end{array}$ & $\begin{array}{l}\text { Flat tube of } \\
\text { LDPE filled } \\
\text { with triolein }\end{array}$ & $\begin{array}{l}\text { Widely used } \\
\text { method, } \\
\text { commercially } \\
\text { available, well- } \\
\text { established } \\
\text { standard } \\
\text { operation } \\
\text { procedures, and } \\
\text { calibration data } \\
\text { available for } \\
\text { many analyte } \\
\text { classes, and } \\
\text { high sensitivity }\end{array}$ & $\begin{array}{l}\text { Complicated } \\
\text { sample } \\
\text { cleanup, } \\
\text { susceptible to } \\
\text { biofouling }\end{array}$ & 1 month & [9] \\
\hline $\begin{array}{l}\text { nd- } \\
\text { SPME }\end{array}$ & $\begin{array}{l}\text { Negligible } \\
\text { depletion- } \\
\text { solid phase } \\
\text { microextrac } \\
\text { tion }\end{array}$ & Equilibrium & $\begin{array}{l}\text { Hydrophobic } \\
\text { chemicals, } \\
\text { including } \\
\text { PAHs, PCBs, } \\
\text { petroleum } \\
\text { hydrocarbons, } \\
\text { organochlorin } \\
\text { e pesticides, } \\
\text { aniline, } \\
\text { phenols }\end{array}$ & $\begin{array}{l}\text { A fiber coated } \\
\text { with a liquid } \\
\text { (polymer), a } \\
\text { solid } \\
\text { (sorbent), or a } \\
\text { combination } \\
\text { of both }\end{array}$ & $\begin{array}{l}\text { Negligible } \\
\text { depletion } \\
\text { extraction, a } \\
\text { cheap, } \\
\text { disposable } \\
\text { device }\end{array}$ & $\begin{array}{c}\text { Low } \\
\text { sensitivity }\end{array}$ & Hours & [10] \\
\hline & $\begin{array}{l}\text { Solvent- } \\
\text { filled } \\
\text { dialysis } \\
\text { membranes }\end{array}$ & Integrative & $\begin{array}{l}\text { Hydrophobic } \\
\text { organic } \\
\text { compounds }\end{array}$ & $\begin{array}{c}\text { Non-polar } \\
\text { solvent } \\
\text { immiscible } \\
\text { with water } \\
\text { filled in a } \\
\text { cellulose } \\
\text { dialysis } \\
\text { membrane }\end{array}$ & $\begin{array}{l}\text { Not prone to } \\
\text { biofouling }\end{array}$ & $\begin{array}{c}\text { Low } \\
\text { sensitivity for } \\
\text { very } \\
\text { hydrophobic } \\
\text { compounds } \\
\text { and solvent } \\
\text { diffuses out } \\
\text { of the sampler } \\
\text { during } \\
\text { deployment }\end{array}$ & 1 month & [11] \\
\hline
\end{tabular}




\begin{tabular}{|c|c|c|c|c|c|c|c|c|}
\hline $\begin{array}{l}\text { TWA- } \\
\text { SPME }\end{array}$ & $\begin{array}{c}\text { Solid-phase } \\
\text { microextrac } \\
\text { tion applied } \\
\text { for the } \\
\text { determinati } \\
\text { on of TWA } \\
\text { concentrati } \\
\text { ons }\end{array}$ & Integrative & BTEX & $\begin{array}{l}\text { A fiber coated } \\
\text { with a liquid } \\
\text { (polymer), a } \\
\text { solid } \\
\text { (sorbent), or a } \\
\text { combination } \\
\text { of both }\end{array}$ & $\begin{array}{c}\text { No need for } \\
\text { extensive } \\
\text { laboratory } \\
\text { calibrations and } \\
\text { sampling rates } \\
\text { can be } \\
\text { estimated using } \\
\text { empirical mass- } \\
\text { transfer models }\end{array}$ & & $\begin{array}{l}\text { A few } \\
\text { minutes }\end{array}$ & [12] \\
\hline $\begin{array}{l}\text { LDPE } \\
\text { and } \\
\text { silicone } \\
\text { strips }\end{array}$ & & Integrative & $\begin{array}{c}\text { Hydrophobic } \\
\text { organic } \\
\text { compounds }\end{array}$ & $\begin{array}{l}\text { Low-density } \\
\text { polyethylene } \\
\text { or silicone } \\
\text { strips }\end{array}$ & $\begin{array}{c}\text { Simple } \\
\text { construction, } \\
\text { inexpensive, } \\
\text { simple sample } \\
\text { processing, and } \\
\text { calibration data } \\
\text { available for } \\
\text { many analyte } \\
\text { classes } \\
\end{array}$ & $\begin{array}{c}\text { Smaller } \\
\text { sampling } \\
\text { capacity than } \\
\text { SPMDs }\end{array}$ & 1 month & [13] \\
\hline
\end{tabular}

Table 2. Passive sampling devices for inorganic contaminants

\begin{tabular}{|c|c|c|c|c|c|c|c|c|}
\hline Sampler & Name & Purpose & Analytes & Construction & Advantages & $\begin{array}{l}\text { Incon- } \\
\text { venience }\end{array}$ & $\begin{array}{l}\text { Deploy- } \\
\text { ment } \\
\text { period }\end{array}$ & $\begin{array}{l}\text { Refe- } \\
\text { rence }\end{array}$ \\
\hline DGT & $\begin{array}{l}\text { Diffusion } \\
\text { gradients } \\
\text { in thin } \\
\text { films }\end{array}$ & $\begin{array}{l}\text { Integrative, } \\
\text { speciation, } \\
\text { screening, } \\
\text { mimicking } \\
\text { biological } \\
\text { uptake }\end{array}$ & $\begin{array}{l}55 \text { metallic } \\
\text { elements } \\
\text { including the } \\
\text { common } \\
\text { heavy metals, } \\
\text { phosphorous, } \\
\text { sulfide, and } \\
{ }^{99} \mathrm{Tc}\end{array}$ & $\begin{array}{l}\text { Two layers of } \\
\text { acrylamide gel } \\
\text { mounted in a } \\
\text { holder device, } \\
\text { one containing } \\
\text { an acceptor } \\
\text { phase, the other } \\
\text { acting as a thin } \\
\text { diffusion layer }\end{array}$ & $\begin{array}{l}\text { Versatile, } \\
\text { well } \\
\text { documented }\end{array}$ & $\begin{array}{l}\text { Complicated } \\
\text { preparation of } \\
\text { the device }\end{array}$ & 1 week & {$[14]$} \\
\hline PLM & $\begin{array}{c}\text { Permeati } \\
\text { on liquid } \\
\text { mem- } \\
\text { brane }\end{array}$ & $\begin{array}{l}\text { Bioavai-lable } \\
\text { metal species }\end{array}$ & $\mathrm{Cu}, \mathrm{Pb}$ & $\begin{array}{l}\text { Microporous } \\
\text { hydrophobic } \\
\text { support } \\
\text { separating test } \\
\text { solution from } \\
\text { receiving } \\
\text { solution }\end{array}$ & $\begin{array}{l}\text { Selectivity of } \\
\text { the sampler } \\
\text { can be } \\
\text { adjusted } \\
\text { using } \\
\text { appropriate } \\
\text { combination } \\
\text { of carrier } \\
\text { media and } \\
\text { receiving } \\
\text { phase }\end{array}$ & $\begin{array}{l}\text { Complicated } \\
\text { preparation of } \\
\text { device }\end{array}$ & Hours & {$[15]$} \\
\hline PIMS & $\begin{array}{l}\text { Passive } \\
\text { integ- } \\
\text { rative } \\
\text { mercury } \\
\text { sampler }\end{array}$ & $\begin{array}{c}\text { Pre- } \\
\text { concentration, } \\
\text { screening }\end{array}$ & $\begin{array}{l}\text { Neutral Hg } \\
\text { species }\end{array}$ & $\begin{array}{l}\text { LDPE lay-flat } \\
\text { tubing }\end{array}$ & $\begin{array}{c}\text { Membrane } \\
\text { characteristics } \\
\text { may be } \\
\text { altered for } \\
\text { control of } \\
\text { sampling } \\
\text { rates }\end{array}$ & $\begin{array}{c}\text { Further } \\
\text { development } \\
\text { necessary for } \\
\text { aquatic } \\
\text { conditions }\end{array}$ & $\begin{array}{l}\text { Weeks- } \\
\text { months }\end{array}$ & {$[16]$} \\
\hline
\end{tabular}




\begin{tabular}{|c|c|c|c|c|c|c|c|c|}
\hline SLMD & $\begin{array}{l}\text { Stabi- } \\
\text { lized } \\
\text { liquid } \\
\text { mem- } \\
\text { brane } \\
\text { device }\end{array}$ & $\begin{array}{l}\text { Pre- } \\
\text { concentration, } \\
\text { in situ } \\
\text { sampling, } \\
\text { determination } \\
\text { of labile } \\
\text { metal ions in } \\
\text { grab samples }\end{array}$ & $\begin{array}{c}\text { Divalent } \\
\text { metal ions }\end{array}$ & $\begin{array}{l}\text { LDPE lay-flat } \\
\text { tubing } \\
\text { containing an } \\
\text { acidic solution } \\
\text { with high } \\
\text { affinity for the } \\
\text { target elements }\end{array}$ & & $\begin{array}{c}\text { Early } \\
\text { development } \\
\text { stage }\end{array}$ & $\begin{array}{l}\text { Days- } \\
\text { weeks }\end{array}$ & [10] \\
\hline SLM & $\begin{array}{c}\text { Supporte } \\
\text { d liquid } \\
\text { membran } \\
\text { e }\end{array}$ & $\begin{array}{l}\text { Integrative } \\
\text { field } \\
\text { sampling, } \\
\text { preconcentrat } \\
\text { ion of trace } \\
\text { elements, } \\
\text { mimicking } \\
\text { biological } \\
\text { membranes }\end{array}$ & $\begin{array}{l}\text { Doubly } \\
\text { charged } \\
\text { cations }\end{array}$ & $\begin{array}{l}\text { A strip solution } \\
\text { with strong } \\
\text { complexing } \\
\text { agent is } \\
\text { separated from } \\
\text { the test solution } \\
\text { by a macro- } \\
\text { porous } \\
\text { hydrophobic } \\
\text { membrane }\end{array}$ & $\begin{array}{l}\text { Versatile, } \\
\text { selectivity of } \\
\text { the sampler } \\
\text { can be } \\
\text { adjusted }\end{array}$ & & Days & [17] \\
\hline $\begin{array}{l}\text { Chem- } \\
\text { catcher }\end{array}$ & & $\begin{array}{c}\text { In situ } \\
\text { sampling, } \\
\text { integrative, } \\
\text { speciation }\end{array}$ & $\begin{array}{c}\mathrm{Cd}, \mathrm{Cu}, \mathrm{Ni}, \\
\mathrm{Pb} \text { and } \mathrm{Zn}\end{array}$ & $\begin{array}{l}\text { Comprises an } \\
\text { immobilized } \\
\text { chelating } \\
\text { acceptor resin } \\
\text { on a PTFE base } \\
\text { and a cellulose } \\
\text { acetate } \\
\text { membrane filter } \\
\text { acting as a thin } \\
\text { diffusion layer }\end{array}$ & $\begin{array}{l}\text { Selectivity of } \\
\text { the sampler } \\
\text { can be } \\
\text { adjusted } \\
\text { using } \\
\text { appropriate } \\
\text { combination } \\
\text { of membrane } \\
\text { and Empore } \\
\text { disks, and } \\
\text { calibration } \\
\text { data available } \\
\text { for many } \\
\text { chemicals }\end{array}$ & & $\begin{array}{l}14 \text { days - } \\
1 \text { month }\end{array}$ & [18] \\
\hline
\end{tabular}

The samplers consist of deionized water enclosed in a low-density polyethylene (LDPE) sleeve (Figure 1). They are deployed adjacent to a target horizon within a screened or open interval of a well. The suggested application is for long-term monitoring of VOCs in wells. Where the screened interval is greater than $10 \mathrm{feet}(\mathrm{ft})$, the potential for contaminant stratification and/or intra-borehole flow within the screened interval is greater than in screened intervals shorter than $10 \mathrm{ft}$. It is important that the vertical distribution of contaminants is determined in wells having 10 -ft-long well screens, and that both the vertical distribution of contaminants and the potential for intra-borehole flow be determined in wells having screens longer than $10 \mathrm{ft}$. The approach is inexpensive and has the potential to eliminate or substantially reduce the amount of purge water removed from the well.

A variety of PDB samplers have been utilized in well applications (Figure 1). Although the samplers vary in specific construction details, a typical PDB sampler consists of a 1- to 2-ft-long LDPE tube closed at both ends and containing laboratory-grade deionized water (Figure 1). The typical diameter for PDB samplers used in a 2-inch-diameter well is approximately 1.2 inches; however, other dimensions may be used to match the well diameter. Equilibration times may be longer for larger diameter PDB samplers. On the outside of the PDB sampler, a low-density polyethylene mesh sometimes is used for protection against abrasion in open boreholes and as a means of attachment at the prescribed depth. The PDB sampler can be positioned at the target horizon by attachment to a weighted line or attachment to a fixed pipe. 


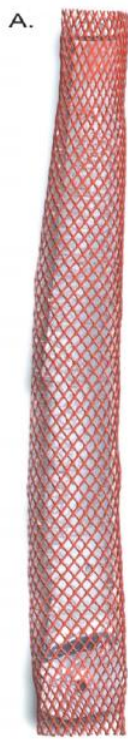

B.

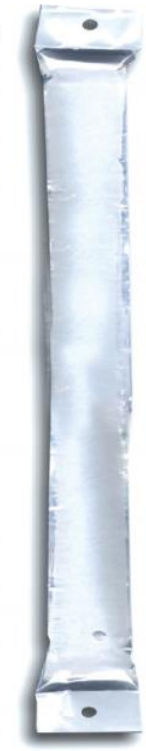

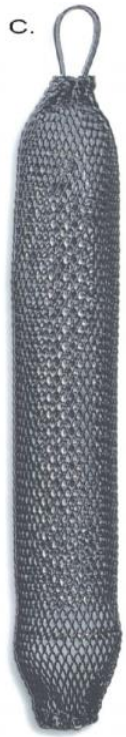

Figure 1. Typical water-filled passive diffusion bag samplers used in wells, including (A) diffusion bag with polyethylene mesh, $(B)$ diffusion bag without mesh, and $(C)$ bag and mesh attached to bailer bottom.

Summary of PDB sampler advantages and limitations:

\subsubsection{Advantages}

1. PDB samplers have the potential to eliminate or substantially reduce the amount of purge water associated with sampling.

2. PDB samplers are inexpensive.

3. The samplers are easy to deploy and recover.

4. Because PDB samplers are disposable, there is no downhole equipment to be decontaminated between wells.

5. A minimal amount of field equipment is required.

6. Sampler recovery is rapid. Because of the small amount of time and equipment required for the sampling event, the method is practical for use where access is a problem or where discretion is desirable (residential communities, business districts, or busy streets where vehicle traffic control is a concern).

7. Multiple PDB samplers, distributed vertically along the screened or open interval, may be used in conjunction with borehole flow meter testing to gain insight into contaminants movement into and out of the well screen or open interval or to locate the zone of highest concentration in the well. Analytical costs when using multiple PDB samplers can sometimes be reduced by selecting a limited number of the samplers for laboratory analysis based on screening using field gas chromatography at the time of sample collection.

8. Because the pore size of LDPE is only about 10 angstroms or less, sediment does not pass through the membrane into the bag. Thus, PDB samplers are not subject to interference from turbidity. None of the data collected suggests that VOCs leach from the LDPE material or that there is a detrimental effect from the PDB material on the VOC sample. 


\subsubsection{Limitations}

1. PDB samplers integrate concentrations over time. This may be a limitation if the sampling goal is to collect a representative sample at a point in time in an aquifer where VOC concentrations substantially change more rapidly than the samplers equilibrate. [19]. The initial equilibration under field conditions may be longer to allow well water, contaminant distribution, and flow dynamics to restabilize following sampler deployment. [20]

2. Water-filled PDB samplers are not appropriate for all compounds. For example, although methyltert-butyl ether and acetone [21,22] and most semi-volatile compounds are transmitted through the polyethylene bag, laboratory tests have shown that the resulting concentrations were lower than in ambient water. A variety of factors influence the ability of compounds to diffuse through the polyethylene membrane. These factors include the molecular size and shape and the hydrophobic nature of the compound. Compounds having a cross-sectional diameter of about 10 angstroms or larger (such as humic acids) do not pass through the polyethylene because the largest (transient) pores in polyethylene do not exceed about 10 angstroms in diameter [23,24,25]. The samplers are not appropriate for hydrophilic polar molecules, such as inorganic ions. Unpublished laboratory test data [26] of semi-volatile compounds in contact with PDB samplers showed a higher concentration of phthalates inside the PDB sampler than outside the PDB sampler, suggesting that the polyethylene may contribute phthalates to the enclosed water. Thus, the samplers should not be used to sample phthalates.

3. VOC concentrations in PDB samplers represent groundwater concentrations in the vicinity of the screened or open well interval that moves to the sampler under ambient flow conditions. This is a limitation if the groundwater contamination lies above or below the well screen or open interval and requires the operation of a pump to conduct contaminants into the well for sampling.

4. In cases where the well screen or open interval transects zones of differing hydraulic head and variable contaminant concentrations, VOC concentrations obtained using a PDB sampler may not reflect the concentrations in the aquifer directly adjacent to the sampler because of vertical transport in the well. However, a vertical array of PDB samplers, used in conjunction with borehole flow meter testing, can provide insight into contaminants movement into or out of the well. This information can then help determine if the use of PDB samplers is appropriate for the well and select the optimal vertical location(s) for the sampler deployment.

5. In wells with screens or open intervals with stratified chemical concentrations, the use of a single PDB sampler set at an arbitrary (by convention) depth may not provide accurate concentration values for the most contaminated zone. However, multiple PDB samplers distributed vertically along the screened or open interval, in conjunction with pump sampling (as appropriate), can be used to locate zone(s) of the highest concentration in the well. Multiple PDB samplers may also be needed to track the zone of maximum concentration in wells where flow patterns through the screened interval change due to groundwater pumping or seasonal water-table fluctuations.

\subsection{Diffusive gradients in thin films (DGT)}

The diffusive gradient in thin films (DGT) device is a development of a similar sampler - the diffusion equilibrium in thin films (DET) device - initially suggested by Davison and co-workers in 1991 [27]. The first reported use of the improved DGT device was in 1994 for measuring $\mathrm{Zn}$ in sea water. The DGT device comprises a gel layer incorporating a binding agent (which acts as a solute sink) and a hydrated acrylamide diffusion gel separating it from the water column. This creates a diffusion layer of well-defined thickness. The initial design of the DGT utilized an ion-exchange resin as the receiving 
phase. Later, Zhang and co-workers [28] demonstrated the applicability of the technique to the determination of trace metals $(\mathrm{Cd}, \mathrm{Cu}, \mathrm{Fe}$, and $\mathrm{Mn})$ in sea water. With a chelating resin embedded in the gel layer, metals could be quantified as low as $4 \mathrm{pmol} / \mathrm{L}$ after deployment for $1 \mathrm{~h}$. The subsequent refinement of the design and the extended range of inorganic pollutants that may be sampled indicate the versatility and the widespread use of the DGT device. In principle, it is possible to sample any labile species for which a suitable binding agent can be embedded into the receiving phase gel.

Also, DGT is based on a simple procedure of measuring soluble metals, which diffuse through a filter and accumulate on a binding agent, the hydrogel. DGT is designed to bind only the species of interest selectively and to accurately control the transport of the substances to the device, allowing the concentration in solution during deployment to be calculated from the laboratory measurement. DGT has been successfully applied in a variety of environmental monitoring projects related to hazardous radionuclides, trace metals, organic contaminants to measure chemical release at a controlled rate. [29]

It is also possible to calculate free ion activity by using different diffusive layers (gels) to trap inorganic and organic species separately and then conducting speciation calculations.

\subsubsection{DGT theory}

The DGT sampler comprises a gel assembly that is enclosed in a piston-like plastic casing (Figure 2). The plastic casing comprises a separate base and cap components which, when pressed together, exclude water from within the device except through a $20 \mathrm{~mm}$ diameter exposure window in the cap. The gel assembly consists of a high-affinity cation exchange binding resin (Chelex-100) embedded in a polyacrylamide hydrogel, which is separated from the bulk solution by a diffusive polyacrylamide gel of standard uniform pore size and thickness, and a cellulose nitrate $0.45 \mu \mathrm{m}$ membrane filter.

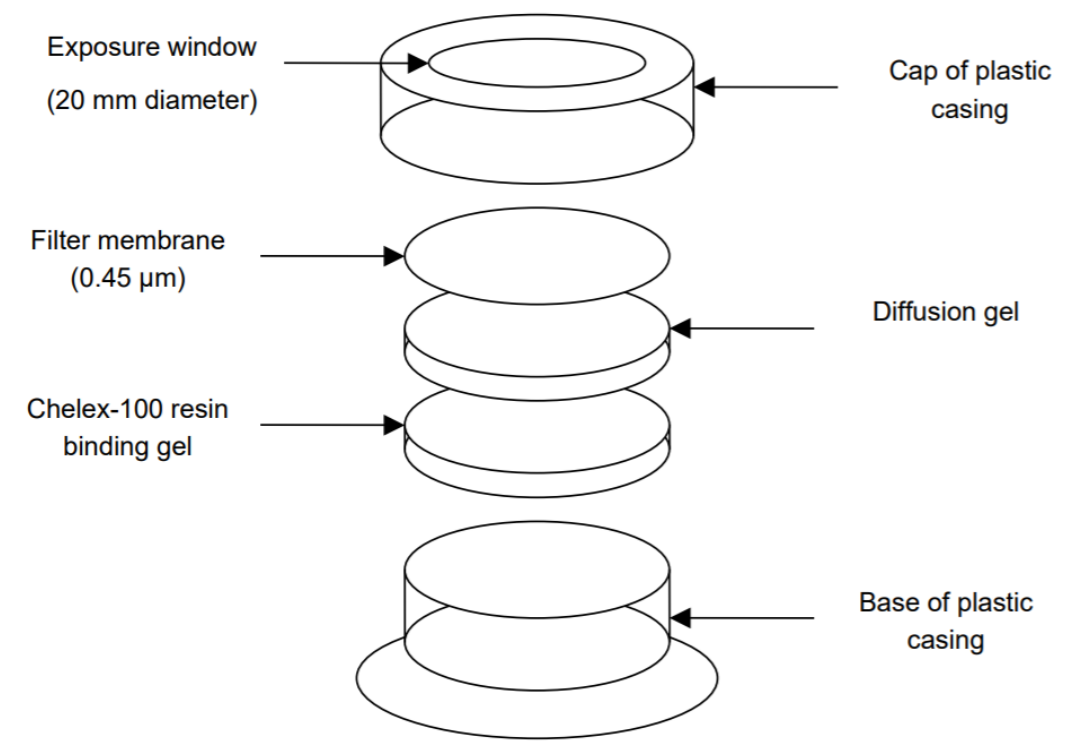

Figure 2. DGT assembly

When DGT devices are submerged in solution, water and its constituent dissolved $(<0.45 \mu \mathrm{m})$ metal species are able to diffuse into the device via the exposure window. After traversing the diffusive layer, metal ions that come in contact with the Chelex-100 become bound and permanently immobilized by binding sites on the resin [30]. Assuming the metal ions bind quickly and efficiently to the resin gel, the 
concentration of metals at the resin-diffusion gel interface effectively remains as zero, resulting in the formation of a linear concentration gradient across the diffusive layer and hence continuous metal uptake until the resin reaches saturation (Figure 2) [31]. The capacity of Chelex-100 resin is $0.4 \mathrm{meq} / \mathrm{mL}$; therefore, the maximum capacity of the binding gel is determined by the amount of Chelex-100 resin it contains, which is approximately equal between individual devices [30].

The DGT measures the amount of metal that diffuses into the device over a period of time per unit area. The kinetics of metal transport into the DGT is controlled by the diffusive gel through which metals diffuse at rates based on their respective diffusion coefficients, as defined by the size of the metal compared to the pore size of the gel (typically 2-5 nm) [32]. The measured flux of metals accumulated in the resin gel over a given period of time is used to calculate the concentration of metals in the bulk solution to which the DGT was exposed.

\subsubsection{Advantages of the DGT technique}

The DGT technique offers a number of advantages over the current methods for water sampling and assessment for the purposes of water quality monitoring.

1. The metals measured by DGT are referred to as DGT-labile metals. They include free metal ions and labile metal complexes, which comprise the fraction of dissolved $(<0.45 \mu \mathrm{m})$ metals that are available for uptake by biota and thereby capable of causing a toxic response. Essentially the DGT-labile concentration is an approximation of the bioavailability of metal [33].

2. Free metal ions present in the solution are able to easily diffuse into the DGT device, where they are bound and immobilized in the resin gel [34]. Metal complexes are also able to enter the device; however, their measurement depends on their stability and whether or not the complex undergoes dissociation during the time taken to traverse the diffusion layer [31,34]. Labile complexes have low stability constants and therefore undergo rapid ligand exchange reactions during which the metal ion becomes available to bind with the resin gel [31]. The ligand exchange for stable complexes is much slower and therefore the metal ion may not become available during its residency in the diffusion layer.

3. In contrast to conventional metal speciation measurements, which involve analysis of water samples, the DGT device is capable of in situ speciation by the differentiation and uptake of DGTlabile species during deployment in solution. The DGT technique also avoids the problematic behavior of metal species in collected water samples as metals that are bound to the resin gel are unaffected by changing physical parameters.

4. Because of the large capacity of the binding gel, DGT devices are able to be deployed for substantial periods of time, over which they continue to accumulate metals [31]. Therefore the resultant DGT measurement is a time-integrated average of metal concentrations over the whole deployment period, including the variations caused by hydrology changes [35].

\subsubsection{Parameters affecting DGT measurement}

Any change or defect in the following parameters will directly affect the DGT measurement.

\section{Temperature}

The rate of mass uptake is influenced by temperature as it is proportionally related to the analyte diffusion coefficient. Values for diffusion coefficients of metals through the polyacrylamide hydrogel are based on those. [34,36]

\section{Flow rate}

In quiescent waters with flow $<0.02 \mathrm{~m} / \mathrm{s}$, a diffusive boundary layer (DBL) develops at the interface between the solution and the solid surface of the DGT sampler [37]. The formation of a DBL essentially 
increases the thickness of the diffusion layer and therefore interferes with the mass transport. Gimpel et al. [37] found that above a low threshold flow of $0.02 \mathrm{~m} / \mathrm{s}$, the mass of metals measured by the DGT was virtually independent of flow, whereas reducing the flow to zero resulted in the DGT only measuring $50 \%$ of the solution concentration. Therefore, if the flow is maintained above the low threshold value of $0.02 \mathrm{~m} / \mathrm{s}$, the thickness of the DBL is assumed to be negligible.

pH

The DGT technique has been found to work accurately for many metals over the $\mathrm{pH}$ range of 4.5 9 [31,37]. Chelex-100 is less efficient at binding metals at low $\mathrm{pH}$ as metal ions are in competition with a high concentration of hydrogen ions present in the solution for binding sites in the resin [31,38]. At lower pH Chelax-100 preferentially binds metals in the order $\mathrm{Cu}>\mathrm{Pb} \gg \gg \mathrm{Zn}>\mathrm{Cd}$ [31].

\section{Ionic strength}

Recent studies have shown that DGT measurement is inaccurate in synthetic laboratory solutions of low ionic strength, as adjusted using soluble sodium and calcium salts (e.g., $\mathrm{NaNO}_{3}$ and $\mathrm{CaCl}_{2}$ ) $[38,39,40]$. Several theories have been suggested to explain DGT behavior at low ionic strength.

Alfaro De la Torre et al. [38] suggested that the DGT technique was not reliable for quantitative measurements of metals in solutions with ionic strength $\left(\Sigma\left[\mathrm{Mg}^{2+}, \mathrm{Na}^{+}, \mathrm{K}^{+}, \mathrm{Ca}^{2+}\right]\right)$ less than $0.2 \mathrm{mM}$. DGT performance in low ionic strength solutions is thought to be hindered by interference in metal diffusion by the counter-diffusion of $\mathrm{Na}^{+}$across the diffusive layer. The overall effect is an increase in the diffusion coefficients of the metals entering the DGT.

Peters et al. [40] have suggested that the erratic behavior observed at low ionic strength is due to the ability of the diffusion gel to bind cations with a low affinity for metal ions competitively; thus, the binding of metal ions is increased when there are insufficient excess cations present in solution to saturate the binding sites.

\section{Summary and conclusion}

This document contains an overview of passive sampling technologies for organic and inorganic pollutants. Two of these passive samplers technologies are described in detail with their advantages and limitations.

The PDB technique has been shown to be a method for organic contaminants; it offers a cost-effective approach to long-term monitoring of (VOCs) at well-characterized sites. [5,6]

The effectiveness of the use of a single PDB sampler in a well is dependent on the assumption that there is horizontal flow through the well screen and that the quality of the water is representative of the groundwater in the aquifer directly adjacent to the screen. If there are vertical components of intra borehole flow, multiple intervals of the formation contributing to flow, or varying concentrations of VOCs vertically within the screened or open interval, then multiple deployments of PDB samplers within a well may be more appropriate for sampling the well. [41]

The DGT technique is a new and innovative method for in situ measurements of free metal ions and labile metal complexes in groundwater, offering an approximation of metal bioavailability. As well as their unique capability for in situ speciation, it has been reported that DGT offers a number of other advantages over other methods, including higher sensitivity and the ability to detect concentration variation over irregular flow [31,35].

In summary, the development of passive sampling technologies still progressing to monitor a wider range of chemicals. 


\section{References}

[1] Vrana, B., Graham, A. M., Ian, J. A., Dominiak, E., Svensson, K., Knutsson, J., Morrison, G., Greenwood, R. (2005). Passive sampling techniques for monitoring pollutants in water. Trends in Analytical Chemistry, 24(10) https://doi.org/10.1016/j.trac.2005.06.006

[2] Robin, M. L. J., Gillham, R. W. (1987). Field Evaluation of Well Purging Procedures. Ground Water Monitoring Review, 7(4). 85-93. https://doi.org/10.1111/j.1745-6592.1987.tb00967.x

[3] Namiesnik, J., Zabiegala, B., Kot-Wasik, A., Partyka, M., Wasik, A.: Anal. Bioanal. Chem. 381 (2005) 279. https://doi.org/10.1007/s00216-004-2830-8

[4] ITRC (Interstate Technology \& Regulatory Council). (2007). Protocol for Use of Five Passive Samplers to Sample for a Variety of Contaminants in Groundwater. DSP-5. Washington, D.C.: Interstate Technology \& Regulatory Council, Diffusion/Passive Sampler Team

[5] Vroblesky, D. A., Hyde, W. T. (1997). Diffusion samplers as an inexpensive approach to monitoring VOCs in groundwater. Ground Water Monitoring and Remediation, 17(3), 177-184. https://doi.org/10.1111/j.1745-6592.1997.tb00593.x

[6] Gefell, M. J., Hamilton, L. A., Stout, D. J.: A comparison between low-flow and passive-diffusion bag sampling results for dissolved volatile organics in fractured sedimentary bedrock, 1999 in Proceedings of the Petroleum and Organic Chemicals in Ground Water - Prevention, Detection, and Remediation Conference, November 17-19, Houston, Texas, pp. 304-315.

[7] Vroblesky, D. A., Hyde, W. T.: Ground Water Monit. Remediat. 17 (1997) 177. https://doi.org/10.1111/j.1745-6592.1997.tb00593.x

[8] Vrana, B., Popp, P., Paschke, A., Schüürmann, G.: Anal. Chem. 73 (2001) 5191. https://doi.org/10.1021/ac010630z

[9] Huckins, J. N., Manuweera, G. K., Petty, J. D., Mackay, D., Lebo, J. A.: Environ. Sci. Technol. 27 (1993) 2489. https://doi.org/10.1021/es00048a028

[10] Heringa, M. B., Hermens, J. L. M.: Trends Anal. Chem. 22 (2003) 575. https://doi.org/10.1016/S0165-9936(03)01006-9

[11] A. So"dergren, Environ. Sci. Technol. 21 (1987) 855. https://doi.org/10.1021/es00163a001

[12] Sukola, K., Koziel, J., Augusto, F., Pawliszyn, J.: Anal. Chem. 73 (2001) 13. https://doi.org/10.1021/ac000903a

[13] Booij, K., Smedes, F., van Weerlee, E. M.: Chemosphere 46 (2002) 1157. https://doi.org/10.1016/S0045-6535(01)00200-4

[14] Davison, W., Zhang, H.: Nature (London) 367 (1994) 546. https://doi.org/10.1038/367546a0

[15] Slaveykova, V. I., Parthasarathy, N., Buffle, J., Wilkinson, K. J.: Sci. Total Environ. 328 (2004) 55. https://doi.org/10.1016/j.scitotenv.2003.10.007

[16] Brumbaugh, W. G., Petty, J. D., May, T. W., Huckins, J. N.: Chemos. Global Change Sci. 2 (2000) 1. https://doi.org/10.1016/S1465-9972(99)00055-0

[17] Jonsson, J. A., Mathiasson, L.: Trends Anal. Chem. 11 (1992) 106. https://doi.org/10.1016/0165-9936(92)85008-S

[18] Persson, L. B., Morrison, G. M., Friemann, J. U., Kingston, J., Mills, G., Greenwood, R.: J. Environ. Monit. 3 (2001) 639. https://doi.org/10.1039/b107959j

[19] Vroblesky, D. A., Campbell, T. R. (2001). Equilibration times, stability, and compound selectivity of diffusion samplers for collection of groundwater VOC concentrations. Advances in Environmental Research, 5(1), 1-12. https://doi.org/10.1016/S1093-0191(00)00036-8

[20] Sivavec, T. M., Baghel, S. S. (2000). General Electric Company, written commun. 
[21] Vroblesky, D. A.: Simple, inexpensive diffusion samplers for monitoring VOCs in ground water, 2000 The Second International Conference on Remediation of Chlorinated and Recalcitrant Compounds, May 22-25, Monterey, California.

[22] Hare, P. (2000). General Electric Company, oral commun.

[23] Flynn, G. L., Yalkowsky, S. H. (1972). Correlation and prediction of mass transport across membrane I: Influence of alkyl chain length on flux determining properties of barrier and diffusant. Journal of Pharmaceutical Science, 61, 838-852. https://doi.org/10.1002/jps.2600610603

[24] Hwang, S. T., Kammermeyer, K. (1975). Membranes in Separations: Malabar, Fla., Robert E. Krieger Publishing Company, Inc., 559 p.

[25] Comyn, J. (1985). Polymer Permeability: New York, Elsevier Applied Science Publishers Ltd, 383 p. https://doi.org/10.1007/978-94-009-4858-7

[26] Vroblesky, D. A. (1998). U.S. Geological Survey, written commun.

[27] Davison, W., Zhang, H.: Nature (London) 367 (1994) 546. https://doi.org/10.1038/367546a0

[28] Zhang, H., Davison, W.: Anal. Chem. 67 (1995) 3391. https://doi.org/10.1021/ac00115a005

[29] Pierzynski, M., Michael, J. Schneegurt, M. (2005). Evaluation of chemical and biological assays as indicators of toxic metal bioavailability in soils. US EPA Final Report, EPA Grant Number: R829418E02.

URL: http://cfpub.epa.gov/ncer_abstracts/index.cfm/fuseaction/display.abstractDetail/abstract/ 6108/report/F.

[30] Bio-Rad Laboratories. (2000). Chelex 100 and Chelex 20 chelating ion exchange resin: Instruction manual. http://www.bio-rad.com/webmaster/pdfs/9184_Chelex.PDF. 2004.

[31] Zhang, H., Davison, W. (1995). Performance characteristics of diffusion gradients in thin films for the in situ measurement of trace metals in aqueous solution. Analytical Chemistry, 67, 33913400. https://doi.org/10.1021/ac00115a005

[32] Zhang, H., Davison, W. (1999). Diffusional characteristics of hydrogels used in DGT and DET techniques. Analytica Chimica Acta, 398, 329-340. https://doi.org/10.1016/S00032670(99)00458-4

[33] Luider, C. D., Crusius, J., Playle, R. C., Curtis, P. J. (2004). Influence of natural organic matter source on copper speciation as demonstrated by $\mathrm{Cu}$ binding to fish gills, by ion selective electrode, and by DGT gel sampler. Environmental Science and Technology, 38, 2865-2872. https://doi.org/10.1021/es030566y

[34] Zhang, H., Davison, W. (1994). In situ speciation of trace components in natural waters using thin-film gels. Letters to Nature, 367, 546-548. https://doi.org/10.1038/367546a0

[35] Meylan, S., Odzak, N., Behra, R., Sigg, L. (2004). Speciation of copper and zinc in natural freshwater: comparison of voltametric measurements, diffusive gradients in thin films (DGT) and chemical equilibrium models. Analytica Chimica Acta, 510, 91-100.

https://doi.org/10.1016/j.aca.2003.12.052

[36] DGT Research Ltd. (2003). DGT-for measurements in water, soils and sediments: Users guide for DGT technique. http://www.dgtresearch.com. April 2003.

[37] Gimpel, J., Zhang, H., Hutchinson, W., Davison, W. (2001). Effect of solution composition, flow and deployment time on the measurement of trace metals by the diffusive gradient in thin films technique. Analytica Chimica Acta, 448, 93-103. https://doi.org/10.1016/S00032670(01)01323-X 
[38] Alfaro-De la Torre, M. C., Beaulieu, P. Y., Tessier, A. (2000). In situ measurement of trace metals in lakewater using the dialysis and DGT techniques. Analytica Chimica Acta, 418, 53-68. https://doi.org/10.1016/S0003-2670(00)00946-6

[39] Sangi, M. R., Halstead, M. J., Hunter, K. A. (2002). Use of diffusion gradient thin film method to measure trace metals in fresh waters at low ionic strength. Analytica Chimica Acta, 546, 241 251. https://doi.org/10.1016/S0003-2670(02)00012-0

[40] Peters, A. J., Zhang, H., Davison, W. (2003). Performance of the diffusive gradients in thin films technique for measurement of trace metals in low ionic strength freshwaters. Analytica Chimica Acta, 478, 237-244. https://doi.org/10.1016/S0003-2670(02)01512-X

[41] ITRC (Interstate Technology \& Regulatory Council). (2001). User's Guide for PolyethyleneBased Passive Diffusion Bag Samplers to Obtain Volatile Organic Compound Concentrations in Wells. DSP-1a. Columbia, South Carolina. 